\title{
DEVELOPMENT OF RURAL AREAS THROUGH FISCAL DECENTRALIZATION
}

\author{
Nadiia Davydenko ${ }^{1}$ Prof. dr hab., Svitlana Boiko ${ }^{2} \mathrm{Ph}$, Alina Buriak ${ }^{3} \mathrm{PhD}$,
}

Inna Demianenko ${ }^{4}$ PhD.

1,3 Department of Finance, National University of Life and Environmental Sciences of Ukraine, Kyiv, Ukraine, 2,4 Department of Finance, National University of Food Technologies, Kyiv, Ukraine

\begin{abstract}
The ratification of the European Charter of Local Self-Government and the adoption of the Concept of the Reform of Local Self-Government and the Territorial Organization of Power in Ukraine in April, 2014 laid the groundwork for the approval of fiscal decentralization and the creation of fiscal frameworks for the development of rural areas. One of the defining conditions of fiscal decentralization is the provision of the local government with financial resources in an amount sufficient to perform their tasks for development of rural areas. Therefore, the purpose of the article is to study the peculiarities of rural development of Ukraine in terms of fiscal decentralization, identify the main problems, and present an argument for the directions towards enhancing the positive impact of fiscal decentralization on the social and economic development of rural areas. The methodological basis of the article is general scientific and special methods of research, in particular: economic and statistical; analysis and synthesis; tabular and graphical.

The conducted research has made it possible to establish that the implementation of fiscal decentralization has resulted in greater interest of village council in increasing revenues to local budgets by transferring the right to receive more tax revenues and non-tax revenues, finding contingency local budgets, improving the efficiency of tax administration and fees. The study gives grounds for proposing approaches to increase the effectiveness of fiscal decentralization in the context of rural development, including expanding of the list of taxes and fees in budget revenues of united territorial community (e.g. corporate income tax, personal income tax, environmental tax); improving the mechanism for providing local budgets with inter-budget transfers from the State Budget of Ukraine; optimization of budget expenditures under the condition that a guaranteed and affordable level of public services is provided; increasing the accountability of local governments in order to prevent corruption; involvement of the population in active participation in development policy of rural areas.
\end{abstract}

Key words: decentralization, fiscal decentralization, RURAL AREAS, united territorial communities.

JEL code: R13, R51, R58, H77

\section{Introduction}

The purpose of the article is to study the peculiarities of rural development of Ukraine in terms of fiscal decentralization, identify the main problems, and present an argument for the directions towards enhancing the positive impact of fiscal decentralization on the social and economic development of rural areas.

The main tasks of the research are to reveal insights into the essence of fiscal decentralization; to identify the peculiarities of the implementation of fiscal decentralization and its impact on the development of rural areas of Ukraine; to present an argument for the directions towards enhancing the positive impact of fiscal decentralization on the social and economic development of rural areas.

Information sources are scientific articles and monographs on fiscal decentralization, data from the Ministry of Finance of Ukraine, the State Statistics Service of Ukraine, and the State Treasury Service of Ukraine.

The methodological basis of the article is general scientific and special methods of research, in particular: economic and statistical - to determine the dynamics and composition of revenues and expenditures of local budgets; analysis and synthesis - to study the structure of revenues and expenditures of local government budgets; tabular and graphical - to represent the results of the study.

\footnotetext{
1 Email: davidenk@nubip.edu.ua

2 Email: svitlanaboyko_@ukr.net

3 Email: alina.v_bu@online.ua

4 Email: i.demianenko@ukr.net
} 
The ratification of the European Charte,r of Local Self-Government (Council of Europe, 2009) and the adoption of the Concept of the Reform of Local Self-Government and the Territorial Organization of Power in Ukraine (Order of the Cabinet of Ministers of Ukraine, 2014), in April, 2014 laid the groundwork for the approval of fiscal decentralization and the creation of fiscal frameworks for the development of rural areas. One of the defining conditions of fiscal decentralization is the provision of the local government with financial resources in an amount sufficient to perform their tasks. As for 2013, only $23.75 \%$ was the share of local budget revenues in the consolidated budget of Ukraine, $13.93 \%$ was the share of local budget revenues (including inter-budgetary transfers) in GDP, 6.63\% was the share of local budget revenues (without inter-budgetary transfers) in GDP. Insufficient revenue of local budgets confirms the relevance of fiscal decentralization and the urgency to reform the financial support of local government, including rural areas.

Research results and discussion

The issues of fiscal decentralization are covered in numerous scientific papers of both foreign and domestic financial scientists. Tanzi V. believed that properly implemented, decentralization provides important economic and political benefits as local jurisdictions improve the efficiency and accountability of public spending. The key to successful decentralization is good planning: decentralization should mean devolving both spending responsibilities and revenue sources-and determining the magnitude of both simultaneously and in advance (Tanzi V., 1995).

Baskaran T., Davoodi H., Feld T. P., Zou H. and Thiessen U. have investigated the relationship between fiscal decentralization and economic growth. Davoodi H., \& Zou H. have found a negative relationship between fiscal decentralization and growth in developing countries, but none in developed countries over the 1970-1989 period (Davoodi H., \& Zou H., 1998). Thiessen U. has analyzed the long-run empirical relationship between per capita economic growth, capital formation and total factor productivity growth, and fiscal decentralisation for the high-income OECD countries. The evidence supports the view that the relationship is positive when fiscal decentralisation is increasing from low levels, but then reaches a peak and turns negative. (Thiessen U., 2003). Baskaran T. \& Feld T. P. studied the relationship between fiscal decentralization and economic growth for 23 OECD countries from 1975 to 2001 and concluded that fiscal decentralization is unrelated to economic growth (Baskaran T., \& Feld T. P., 2009).

Decentralization essentially is a matter of the devolution of power from the centre to the periphery. More precisely, fiscal decentralization generally refers to the devolution of taxing and spending powers from the control of central government authorities to government authorities either at sub-national levels (regional, provincial, municipal etc.) (Boschmann N., 2009).

The reform in the administrative and territorial structure and the system of financial support of local governments, taking into account the possibility to form the united territorial communities, was the starting point of fiscal decentralization in Ukraine. Thus, special conditions for the development of rural areas have been created - the possibility to create a new type of administrative and territorial units (united territorial community) or maintaining the existing type of administrative and territorial units (village, urban-type settlement). 


\section{Comparative characteristics of the main revenues of villages' and urban-type settlements' budgets in terms of fiscal decentralization}

\begin{tabular}{|c|c|c|c|}
\hline \multirow[b]{2}{*}{ Indicators } & \multirow[b]{2}{*}{$\begin{array}{l}\text { The period } \\
\text { before } \\
\text { decentralization } \\
(2014)\end{array}$} & \multicolumn{2}{|c|}{$\begin{array}{l}\text { The period during } \\
\text { decentralization }\end{array}$} \\
\hline & & $\begin{array}{l}\text { for refusing } \\
\text { to unite } \\
\text { territorial } \\
\text { communities }\end{array}$ & $\begin{array}{l}\text { in case of } \\
\text { formation of } \\
\text { united } \\
\text { territorial } \\
\text { communities }\end{array}$ \\
\hline \multicolumn{4}{|c|}{ The revenues of the General Fund of budgets } \\
\hline personal income tax & $25 \%$ & & $60 \%$ \\
\hline excise tax on retailers of excisable goods & & $100 \%$ & $100 \%$ \\
\hline $\begin{array}{l}\text { enterprise profit tax for the municipal enterprises and financial } \\
\text { institutions }\end{array}$ & $100 \%$ & $100 \%$ & $100 \%$ \\
\hline property tax & & $100 \%$ & $100 \%$ \\
\hline flat tax & & $100 \%$ & $100 \%$ \\
\hline $\begin{array}{l}\text { the rent for use of subsoil resources for the extraction of minerals of } \\
\text { local significance; rent for use of subsoil resources for the purposes } \\
\text { unrelated to extraction of minerals; rent for special use of water } \\
\text { from water bodies of local significance; rent for special use of forest } \\
\text { resources (other than the rent for special use of forest resources } \\
\text { with regard to timber harvested in the course of final felling) }\end{array}$ & $100 \%$ & $100 \%$ & $100 \%$ \\
\hline $\begin{array}{l}\text { the rent for use of subsurface resources for the extraction of oil, } \\
\text { natural gas, and gas condensate }\end{array}$ & & & $3 \%$ \\
\hline rent for the use of national-significance subsurface resources & & & $5 \%$ \\
\hline rent for the use of subsoil for amber mining & & & $30 \%$ \\
\hline land tax & $100 \%$ & & \\
\hline $\begin{array}{l}\text { local taxes and charges (except flat tax, tax for immovable property } \\
\text { other than land) }\end{array}$ & $100 \%$ & & \\
\hline fixed agricultural tax & $100 \%$ & & \\
\hline fee for temporally free funds & $100 \%$ & $100 \%$ & $100 \%$ \\
\hline the rent for water bodies of local significance & $100 \%$ & $100 \%$ & $100 \%$ \\
\hline concession fees with regard to municipal properties & & $100 \%$ & $100 \%$ \\
\hline $\begin{array}{l}\text { environmental tax (except the environmental tax levied for creation } \\
\text { of radioactive waste (including already accumulated waste) and/or } \\
\text { temporary storage of radioactive waste by its producers in excess of } \\
\text { the period established by special license terms) }\end{array}$ & & $25 \%$ & \\
\hline \multicolumn{4}{|c|}{ The revenues of the Special Fund of budgets } \\
\hline motor vehicle first registration charge & $50 \%$ & & \\
\hline tax for immovable property other than land & $100 \%$ & & \\
\hline flat tax & $100 \%$ & & \\
\hline $\begin{array}{l}\text { funds from compensation for loss of agricultural and forest } \\
\text { production }\end{array}$ & $60 \%$ & $60 \%$ & \\
\hline $\begin{array}{l}\text { monetary penalties for damage caused by violation of environmental } \\
\text { legislation as a result of economic and other activities }\end{array}$ & $50 \%$ & $50 \%$ & \\
\hline $\begin{array}{l}\text { deduction of the cost of drinking water by business entities that sell } \\
\text { drinking water through centralized water supply systems with } \\
\text { deviations from the relevant standards }\end{array}$ & $10 \%$ & $10 \%$ & \\
\hline $\begin{array}{l}\text { environmental tax (except the environmental tax levied for creation } \\
\text { of radioactive waste (including already accumulated waste) and/or } \\
\text { temporary storage of radioactive waste by its producers in excess of } \\
\text { the period established by special license terms) }\end{array}$ & $25 \%$ & & \\
\hline
\end{tabular}




\section{Source: author's compilation based on Budget Code of Ukraine}

During 2015, based on the provisions of the Law of Ukraine "On Voluntary Unification of Territorial Communities" from February 5, 2015 going under No. 157-VIII and the Resolution of the Cabinet of Ministers of Ukraine "On approval of the Methodology for the formation of capable territorial communities" from April 8, 2015 going under No. 214, the mechanism of voluntary unification of territorial communities was created; the amendments to the Budget Code of Ukraine in terms of forming the revenue and expenditure part of budgets and the Tax Code of Ukraine in terms of taxation of agricultural enterprises were made. Established that the simplified tax system in 2015 has undergone significant changes, combined with a single tax fixed agricultural tax, reduced the number of groups simplified, reduced tax rates for the third group gradually introduced cash registers in cash settlements (Davydenko N., 2016).

In accordance with the Budget Code of Ukraine, there are the sources of composition of the revenues of local budgets of rural areas either belonging to the united territorial communities (Article 64) or maintaining the existing form of administrative and territorial structure (Article 69). The common component of budget revenues of rural areas are excise tax on sales by retail trade economic entities of excisable goods; enterprise profit tax for municipal enterprises and financial institutions; property tax and single tax; proceeds from the rent for use of a property complex and other municipally-owned property; the rent for use of subsoil resources for the extraction of minerals; use of subsoil resources for the purposes unrelated to extraction of minerals of local significance; rent for special use of water from water bodies of local significance; rent for special use of forest resources; fee for placement of temporarily idle funds; concession fees with regard to municipal properties; the rent for water bodies (parts thereof), which are provided for use on lease terms etc. (Table 1 ).

Thus, the fiscal advantage of amalgamation of village and urban-type settlement communities is the crediting of $60 \%$ of personal income tax paid (transferred) in rural areas. Personal income tax in Ukraine is the main direct budget-forming tax. At the beginning of fiscal decentralization, the fiscal significance of the personal income tax was realized by providing one-sixth of the revenues of the Consolidated Budget of Ukraine and more than a half of the revenues of local budgets (Boiko S .V., Drahan O. O., 2016).

The experience of creation of the united territorial communities shows the use of the possibility of voluntary amalgamation of territorial communities of rural areas (villages and urban-type settlements) (Figure 1) and the creation of 982 united territorial communities in 2015-2020, which united 11073.77 thousand people and 4,487 local councils by the following division: Vinnytsia region - 46 UTC against 156 local governments, Volyn region - 54 UTC against 235 local governments, Dnipropetrovsk region - 71 UTC against 229 local governments, Donetsk region - 13 UTC against 74 local governments, Zhytomyr region - 56 UTC against 412 local governments, Zakarpattia region - 17 UTC against 61 local governments, Zaporizhzhia region - 56 UTC against 199 local governments, Ivano-Frankivsk region 39 UTC against 176 local governments, Kyiv region - 24 UTC against 142 local governments, Kirovohrad region - 27 UTC against 81 local governments, Luhansk region - 18 UTC against 75 local governments, Lviv region - 41 UTC against 174 local governments, Mykolaiv region - 42 UTC against 146 local governments, Odesa region - 37 UTC against 158 local governments, Poltava region - 53 UTC against 195 local governments, Rivne region - 45 UTC against 148 local governments, Sumy region - 38 UTC against 187 local governments, Ternopil region - 54 UTC against 314 local governments, Kharkiv region 23 UTC against 114 local governments, Kherson region - 33 UTC against 115 local governments, Khmelnytskyi region - 51 UTC against 370 local governments, Cherkasy region - 57 UTC against 222 local governments, Chernivtsi region - 37 UTC against 132 local governments, Chernihiv region - 50 UTC against 372 local governments. 


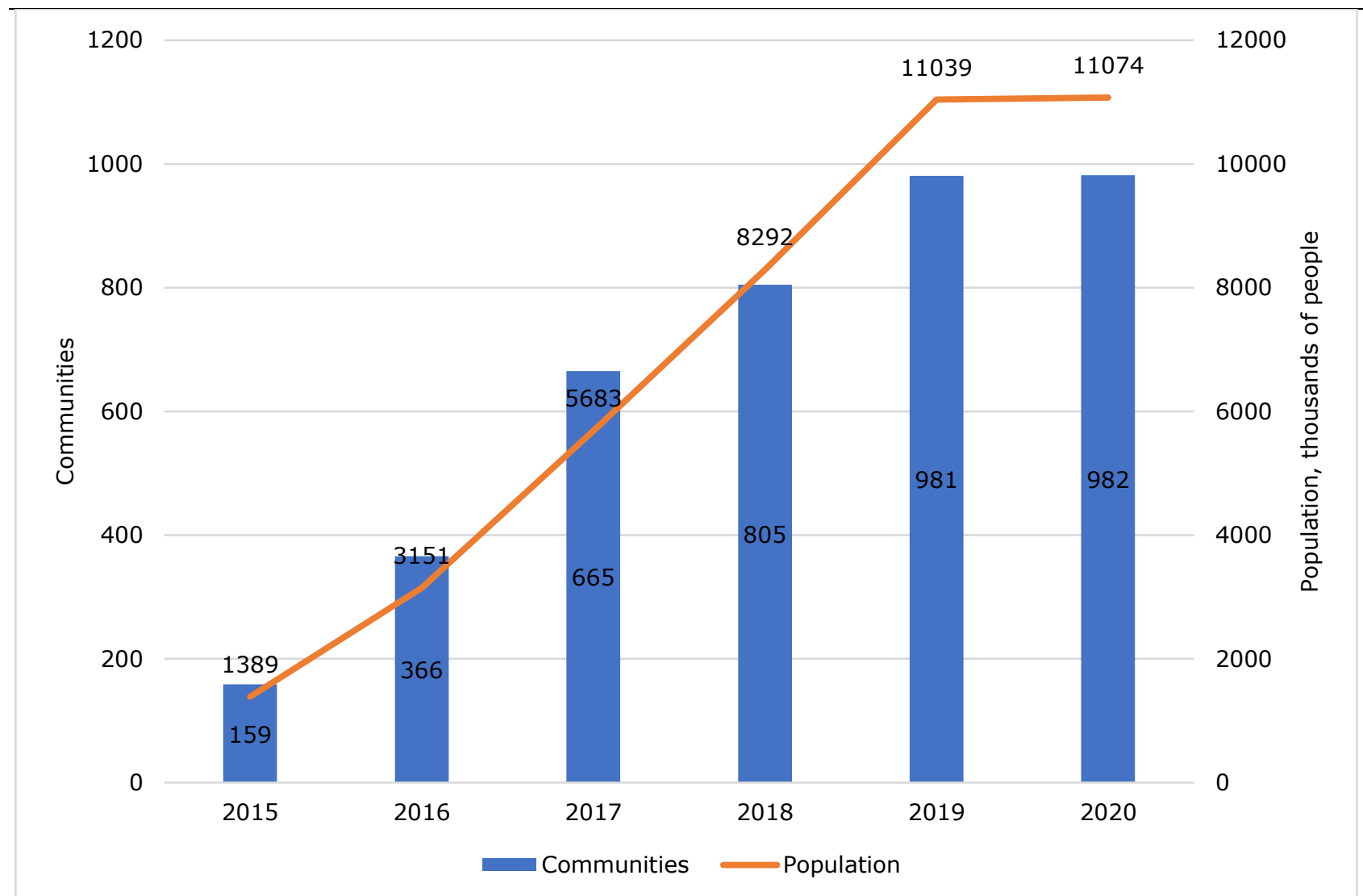

Source: author's calculations based on data from www.decentralization.gov.ua (Decentralization, 2021)

Figure 1. Dynamics of united territorial communities in 2015-2020

The functioning of the united territorial communities as full-fledged and independent administrative-territorial units is possible only if the amount of financial potential and the ability to form the revenue part of the budget are sufficient to cover expenditures. Since the personal income tax is considered as budget-forming one for the budget of Ukraine, the legislator has determined its main role not only in forming of the budget revenues of the united territorial communities.

Article 99 of the Budget Code of Ukraine determines the methodological basis for assessing the level of taxpaying capacity of budgets by comparing the income tax of individuals from the budget of the united territorial community with the average income tax of individuals from the budgets of the united territorial communities in Ukraine in per capita terms.

Fig. 2 demonstrates the distribution of budgets of the united territorial communities in 2016-2019 by the tax capacity index. 


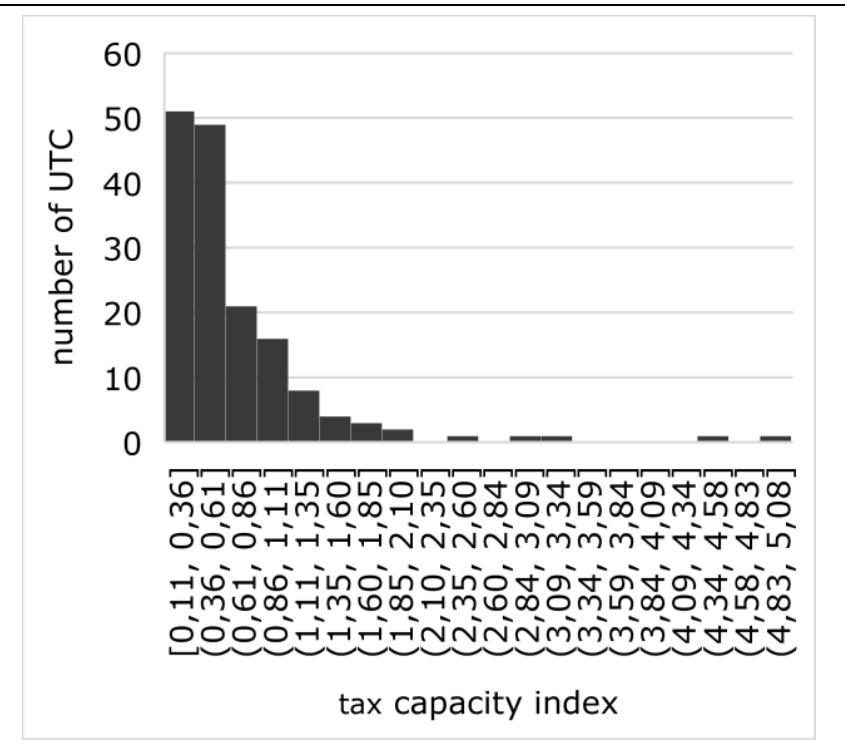

a) 2016 year

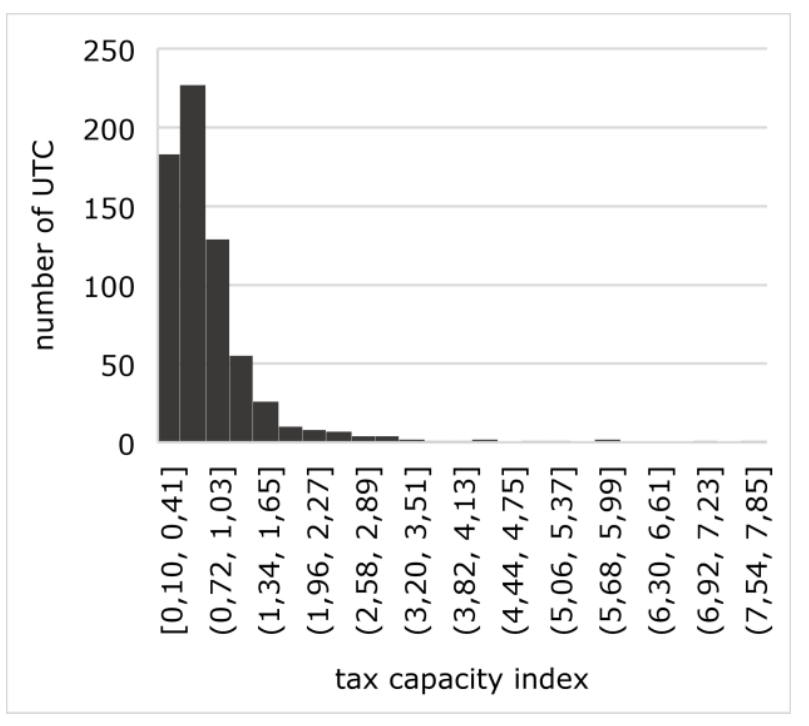

c) 2018 year

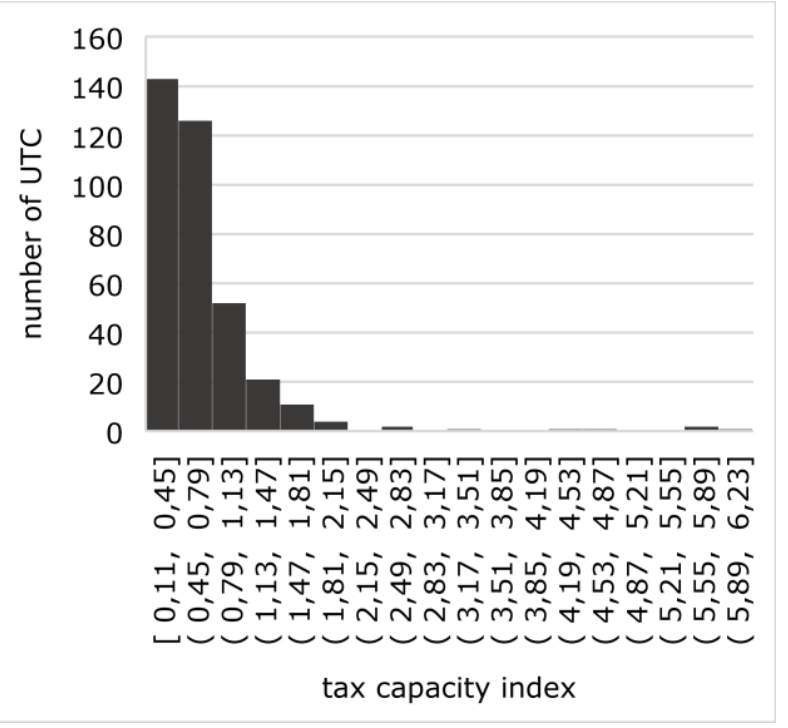

b) 2017 year

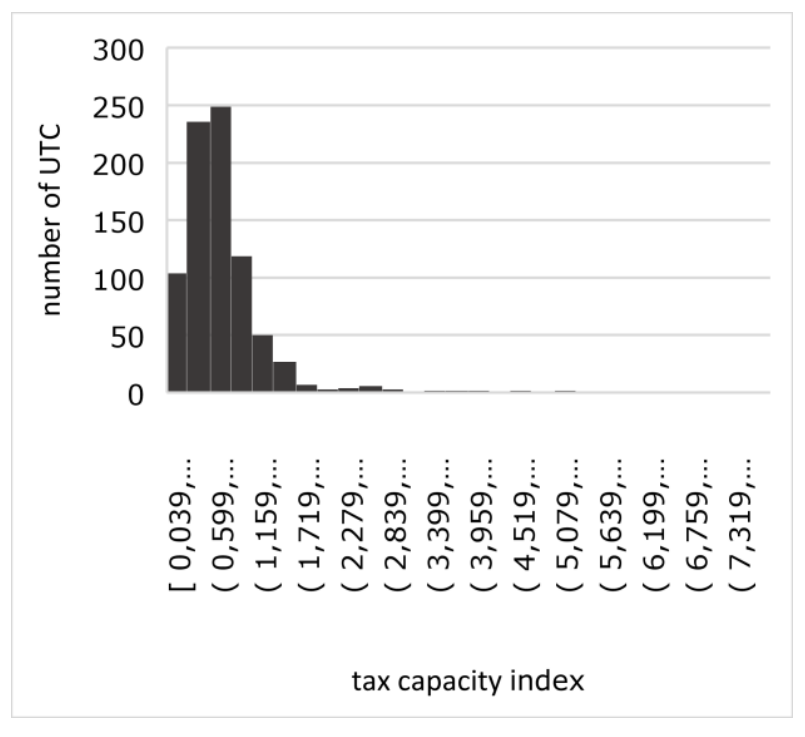

d) 2019 year

\section{Source: author's calculations based on Ministry of Finance of Ukraine}

\section{Figure 2. Distribution of budgets of the united territorial communities} by the tax capacity index

It is worth noting the partial deviation from the provisions of the Law of Ukraine "On Voluntary Unification of Territorial Communities" from February 5, 2015 going under No. 157-VIII and the Resolution of the Cabinet of Ministers of Ukraine "On approval of the Methodology for the formation of capable territorial communities" from April 8, 2015 going under No. 214 in terms of ensuring the formation of financial resources by individual united territorial communities, the index of taxpaying capacity of budgets does not exceed 0.25 for village and urban-type settlement territorial communities. In 2016, the share of budgets of the united territorial communities with a taxpaying capacity index of less than 0.9 was $79.87 \%$ (127 budgets), in $2017-77.53 \%$ (283 budgets, amongst 165 were newly formed), in $2018-72.93 \%$ (485 budgets, amongst 218 were newly formed), 2019 - 73.21\% (604 budgets, amongst 119 were newly formed). It can be concluded that a positive trend towards reduction of the share of subsidized budgets of the united territorial communities takes place on condition of their maintained high share in the total budget. 
To identify the extent of fiscal decentralization, an analysis of the share of local budget revenues in GDP, the share of local budget revenues in the Consolidated Budget revenues was carried out.

Analysis of data from the Ministry of Finance of Ukraine on the redistribution of GDP through local budgets (Figure 3) shows an increase in the relative indicator (local budget revenues / GDP). Thus, in 2015, the share of local budget revenues (without inter-budget transfers) was $6.06 \%$ against $7.69 \%$ in 2017 . It was a result of the redistribution of tax revenues in favour of local budgets in terms of personal income tax, excise tax on retailers of excisable goods etc.

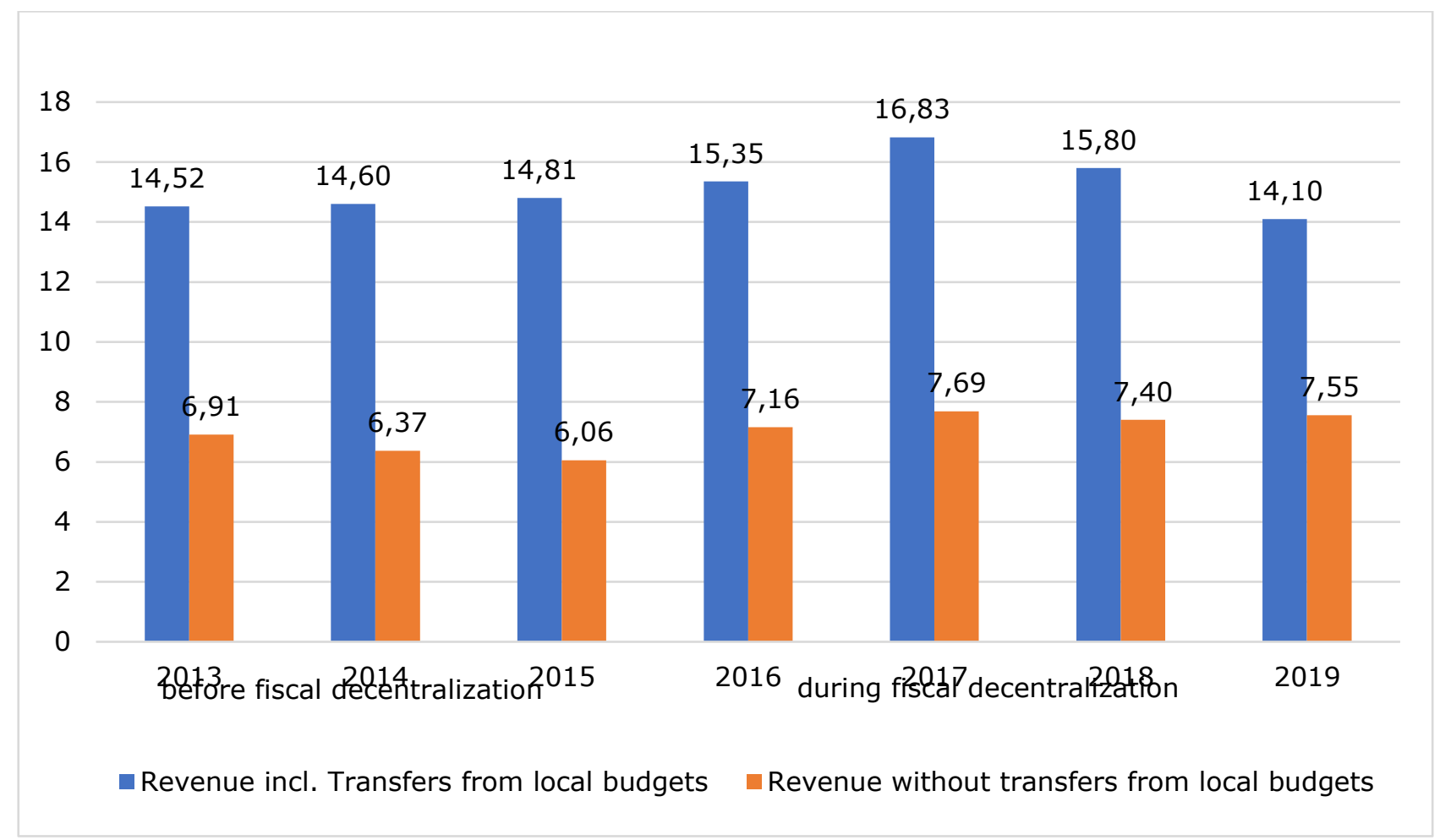

\section{Source: author's calculations based on Ministry of Finance of Ukraine}

\section{Figure 3. Dynamics of the share of local budget revenues in GDP of Ukraine, \%}

The share of revenue including transfers from local budgets in GDP fluctuated at the level from $14.10 \%$ to $16.83 \%$. It indicates an increase in the indicator during the first years of fiscal decentralization, whereas in 2018-2019 the decrease in the corresponding indicator was noted. In 2019, the share of revenue including transfers from local budgets to GDP of Ukraine was $14.10 \%$ that exceeds the average level of revenue including transfers from local budgets to GDP in EU member states - $10.6 \%$ (Figure 4). The extent of variation in the share of local budget revenues in GDP in EU member states was high in 2019: from $32.8 \%$ (Denmark) to $0.5 \%$ (Malta). The value of the share of revenue including transfers from local budgets in GDP in 2019, which exceeds the value of Ukraine, is observed in Denmark (32.8 \%), Finland (20.9\%), Sweden (24.3\%), Norway (16.8\%).

In 2019, the share of revenue including transfers from local budgets in the revenues of the Consolidated Budget of Ukraine was $43.46 \%$, which was close to the average indicator in the EU member states - $28 \%$. The highest level of fiscal decentralization of income is in Italy (50.27\%), Latvia (54.37\%), France (58.83\%), Germany (63.30 \%), Switzerland (64.38\%), Poland (64.54\%), Sweden (79.50 \%), Denmark $(82.85 \%)$, and Finland (85.05\%) (Figure 4$)$. The share of revenue including transfers from local budgets in the revenues of the Consolidated Budget of Ukraine in 2019 was $23.28 \%$ against $18.48 \%$ in 2015 , which confirms the gradual increase in own revenues of local budgets and their share in the consolidated budget. 
In 2014-2019, the absolute amount of revenues of local budgets without transfers has tripled, which confirms the effectiveness of the implemented measures of fiscal decentralization. In 2016, the growth rate of local budget revenues (without inter-budget transfers) was $41.72 \%$ with a tendency to slow down during the following years (2017 - 34.41\%, 2018 - $14.81 \%, 2019$ - $13.95 \%)$. It should be noted that the dynamics of revenues of local budgets without transfers is determined, first of all, by its positive dynamics of tax revenues (growth rate - 3.10 times, absolute growth - UAH 183212 million), then - non-tax revenues (growth rate - 2.13 times, absolute growth - UAH 13851 million) and revenues from capital transactions (growth rate - 2.60 times, absolute growth - UAH 1801 million).

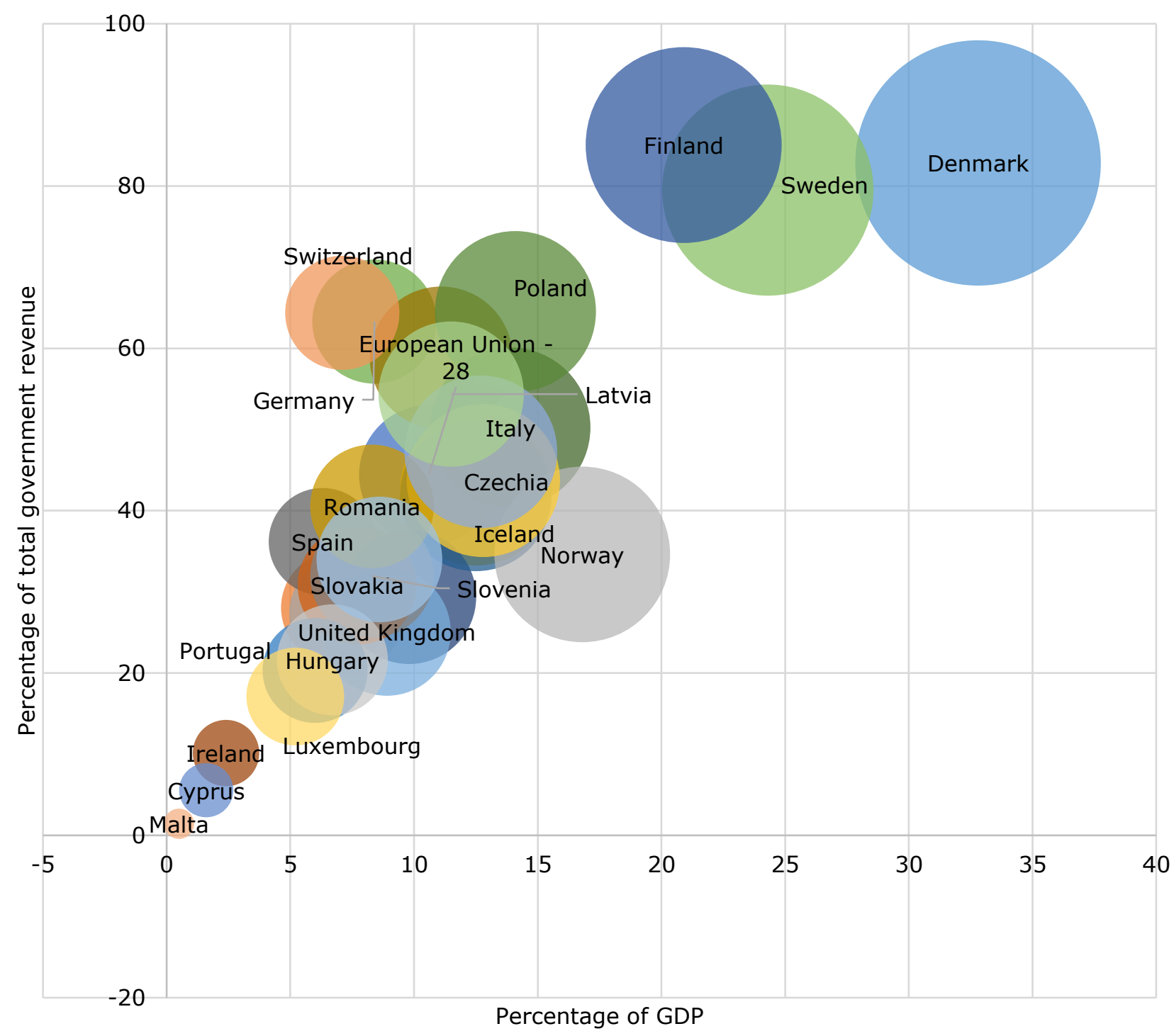

Source: author's calculations based on Eurostat

Figure 4. Dynamics of the share of budget revenues of local budgets in GDP and total government revenue, \%

The implementation of fiscal decentralization has resulted in structural changes in revenues of local budgets of Ukraine in favour of tax revenues, the share of which in 2019 was $90.11 \%$ (Table 2). 
Revenues of local budgets of Ukraine without transfers, \%

\begin{tabular}{|l|c|c|c|c|c|c|c|}
\hline \multicolumn{1}{|c|}{ Indicators } & \multicolumn{2}{|c|}{$\begin{array}{c}\text { The period } \\
\text { before fiscal } \\
\text { decentralization }\end{array}$} & \multicolumn{5}{c}{$\begin{array}{c}\text { The period during fiscal } \\
\text { decentralization }\end{array}$} \\
\cline { 2 - 8 } & $\mathbf{2 0 1 3}$ & $\mathbf{2 0 1 4}$ & $\mathbf{2 0 1 5}$ & $\mathbf{2 0 1 6}$ & $\mathbf{2 0 1 7}$ & $\mathbf{2 0 1 8}$ & $\mathbf{2 0 1 9}$ \\
\hline Tax revenues & 86.71 & 86.38 & 81.52 & 86.03 & 87.59 & 88.25 & 90.11 \\
\hline $\begin{array}{l}\text { Taxes on revenue, taxes on } \\
\text { income, taxes on the market } \\
\text { value increase }\end{array}$ & 62.05 & 62.13 & 49.14 & 49.69 & 51.04 & 55.97 & 58.53 \\
\hline personal income tax & 61.41 & 61.88 & 45.59 & 46.25 & 48.22 & 52.44 & 55.13 \\
\hline $\begin{array}{l}\text { Rent and fees for use of other } \\
\text { natural resources }\end{array}$ & 14.27 & 14.40 & 1.79 & 1.47 & 1.08 & 1.83 & 1.76 \\
\hline $\begin{array}{l}\text { Domestic taxes on goods and } \\
\text { services }\end{array}$ & 1.29 & 0.16 & 6.38 & 6.81 & 5.73 & 5.24 & 4.57 \\
\hline Local taxes and charges & 6.95 & 7.97 & 22.44 & 24.75 & 22.91 & 23.16 & 24.51 \\
\hline Other taxes and charges & 1.59 & 1.33 & 1.77 & 3.31 & 6.82 & 2.06 & 0.75 \\
\hline Non-tax revenues & 11.53 & 12.12 & 16.72 & 12.80 & 11.32 & 10.64 & 8.70 \\
\hline $\begin{array}{l}\text { Revenues from capital } \\
\text { transactions }\end{array}$ & 1.31 & 1.12 & 1.35 & 0.82 & 0.82 & 0.81 & 0.98 \\
\hline $\begin{array}{l}\text { Official transfers from the } \\
\text { European Union, foreign } \\
\text { governments, international } \\
\text { organizations, donor agencies }\end{array}$ & 1.31 & 0.00 & 0.07 & 0.05 & 0.01 & 0.04 & 0.01 \\
\hline Special funds & 0.45 & 0.38 & 0.34 & 0.29 & 0.27 & 0.26 & 0.20 \\
\hline Revenues & 100.00 & 100.00 & 100.00 & 100.00 & 100.00 & 100.00 & 100.00 \\
\hline
\end{tabular}

Source: author's calculations based on Ministry of Finance of Ukraine

The highest fiscal efficiency was provided by domestic taxes revenues on goods and services (excise tax on retailers of excisable goods), local taxes and charges (property tax, vehicle tax, flat tax, tourist fee). All of the abovementioned tax revenues are credited to the budgets of villages, regardless of the formation of united territorial community. According to the criterion of fiscal potential of local taxes and fees, cluster ranking of regions was carried out. Low potential of local taxation was determined in 15 regions, average potential in 3 regions (Dnipropetrovsk, Zaporizhzhia, Poltava), and high potential in 4 regions (Kyiv, Kharkiv, Lviv, Odesa) (Boiko S. V., 2016). 
Comparative characteristics of the main expenditures of villages' and urban-type settlements' budgets in terms of fiscal decentralization

\begin{tabular}{|c|c|c|c|}
\hline \multirow[b]{2}{*}{ Expenditure } & \multirow[b]{2}{*}{ 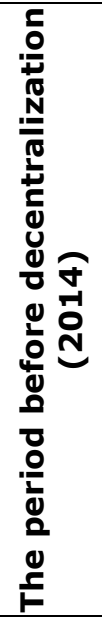 } & \multicolumn{2}{|c|}{$\begin{array}{l}\text { The period during } \\
\text { decentralization }\end{array}$} \\
\hline & & 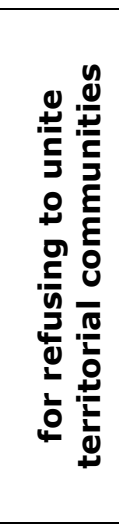 & 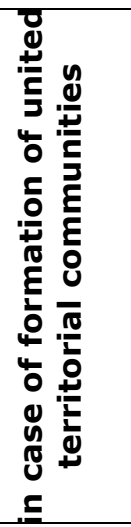 \\
\hline Local government & + & + & + \\
\hline \multicolumn{4}{|l|}{ Education } \\
\hline pre-school education & + & & + \\
\hline general secondary education & + & & + \\
\hline pre-higher education & & & + \\
\hline higher education & & & + \\
\hline out-of-school education & & & + \\
\hline \multicolumn{4}{|l|}{ Health } \\
\hline primary medical care & & & + \\
\hline $\begin{array}{l}\text { co-financing of payment for medical services provided } \\
\text { under the program of state guarantees of medical care }\end{array}$ & & & + \\
\hline \multicolumn{4}{|l|}{ Cultural and physical development } \\
\hline $\begin{array}{l}\text { village, town palaces and houses of culture, clubs, leisure } \\
\text { centres and libraries }\end{array}$ & + & & + \\
\hline $\begin{array}{l}\text { maintenance and educational work of children's and } \\
\text { youth sports schools }\end{array}$ & & & + \\
\hline cultural and artistic programs of local significance & & + & + \\
\hline activities in physical culture and sports & & & + \\
\hline \multicolumn{4}{|l|}{ Social protection and social security } \\
\hline $\begin{array}{l}\text { programs of local significance for children, youth, } \\
\text { women, families }\end{array}$ & & + & + \\
\hline $\begin{array}{l}\text { compensation to individuals who provide social services } \\
\text { to the elderly, persons with disabilities, children with } \\
\text { disabilities }\end{array}$ & & + & + \\
\hline \multicolumn{4}{|l|}{ Housing and utilities } \\
\hline $\begin{array}{l}\text { local programs for the development of housing and } \\
\text { communal services and improvement of settlements }\end{array}$ & & + & + \\
\hline \multicolumn{4}{|l|}{ Transport } \\
\hline $\begin{array}{l}\text { construction, reconstruction, repair and maintenance of } \\
\text { roads }\end{array}$ & & + & + \\
\hline
\end{tabular}


The increase in revenues of the budgets of villages and rural settlements, united territorial community occurred simultaneously with the increase in the expenditure authority in such areas as education, health, cultural and physical development, social protection and social security, housing and utilities etc. (Table 3 ).

Identification of the impact of the fiscal decentralization on the development of the rural areas of Ukraine is realized through the analyses of the dynamics and structure of expenditures of local budgets. In 2019, the expenditure of local budgets of Ukraine without transfers was UAH 5346344 million, that is 2.5 times higher than in 2014. Considering the expenditure of local budgets by functional classification, we note, that the increase in the overall indicator is due to an increase in the expenditure for economic affairs - 9 times, public order, security and judiciary - 5 times, environmental protection - 4 times, education - 3 times, housing and utilities, health, cultural and physical development, social protection and social security 2 times.

Table 4

Expenditure of local budgets of Ukraine without transfers, \%

\begin{tabular}{|l|c|c|c|c|c|c|c|}
\hline \multirow{2}{*}{\multicolumn{1}{|c|}{ Indicators }} & \multicolumn{3}{|c|}{$\begin{array}{c}\text { The period } \\
\text { before fiscal } \\
\text { decentralization }\end{array}$} & \multicolumn{5}{c|}{$\begin{array}{c}\text { The period during } \\
\text { fiscal decentralization }\end{array}$} \\
\cline { 2 - 8 } & $\mathbf{2 0 1 3}$ & $\mathbf{2 0 1 4}$ & $\mathbf{2 0 1 5}$ & $\mathbf{2 0 1 6}$ & $\mathbf{2 0 1 7}$ & $\mathbf{2 0 1 8}$ & $\mathbf{2 0 1 9}$ \\
\hline General public services & 5.32 & 4.93 & 5.25 & 4.68 & 4.86 & 5.08 & 6.26 \\
\hline Defence & 0.001 & 0.92 & 0.004 & 0.002 & 0.003 & & \\
\hline $\begin{array}{l}\text { Public order. security and } \\
\text { judiciary }\end{array}$ & 0.10 & 0.11 & 0.12 & 0.11 & 0.13 & 0.20 & 0.23 \\
\hline Economic affairs & 4.33 & 4.13 & 6.90 & 10.04 & 11.40 & 13.70 & 14.68 \\
\hline Environmental protection & 0.46 & 0.40 & 0.53 & 0.43 & 0.53 & 0.53 & 0.61 \\
\hline Housing and utilities & 3.49 & 7.92 & 5.66 & 5.06 & 5.54 & 5.33 & 6.17 \\
\hline Health & 22.31 & 20.84 & 21.50 & 18.20 & 17.48 & 16.55 & 16.11 \\
\hline $\begin{array}{l}\text { Cultural and physical } \\
\text { development }\end{array}$ & 3.92 & 4.02 & 3.47 & 3.45 & 3.36 & 3.35 & 3.87 \\
\hline Education & 34.18 & 31.96 & 30.33 & 27.32 & 27.87 & 29.42 & 33.56 \\
\hline $\begin{array}{l}\text { Social protection and social } \\
\text { security }\end{array}$ & 25.90 & 25.70 & 26.23 & 30.71 & 28.83 & 25.83 & 18.50 \\
\hline Expenditures & 100.00 & 100.00 & 100.00 & 100.00 & 100.00 & 100.00 & 100.00 \\
\hline
\end{tabular}

Source: author's calculations based on Ministry of Finance of Ukraine

In accordance with the calculated indicators of the structure of the expenditure of local budgets without transfers (Table 4), expenditure on education, social protection and social security, health prevail. Analysing the level of government expenditures are prevailing, Davydenko N. and Pasichnyk Y. conclude that "they have a wide range of fluctuations - both by years and by country. ... all countries experienced their growth, which was the consequence of government actions in support of the poor, in particular on social benefits. Ukraine had the lowest level of these expenditures for almost all of the year, despite annual external and internal borrowings of 2-3 billion USD." (Davydenko N., Pasichnyk Y., 2017).

\section{Conclusions}

Thus, the implementation of fiscal decentralization has resulted in greater interest of local governments (village and urban-type settlement council) in increasing revenues to local budgets by transferring the right to receive more tax revenues and non-tax revenues, finding contingency local budgets, improving the 
efficiency of tax administration and fees (primarily personal income tax, excise tax on retailers of excisable goods, property tax, vehicle tax, flat tax). In terms of the use of local budgets, there is a need to place emphasis on forming the most appropriate structure of budget expenditures with the predominance part of expenditures in such areas as education, social protection and social security, health, economic affairs. It will create conditions for sustainable social and economic development of rural areas.

The study gives grounds for proposing approaches to increase the effectiveness of fiscal decentralization in the context of rural development, including expanding of the list of taxes and fees in budget revenues of united territorial community (e.g. corporate income tax, personal income tax, environmental tax); improving the mechanism for providing local budgets with inter-budget transfers from the State Budget of Ukraine; optimization of budget expenditures of united territorial communities under the condition that a guaranteed and affordable level of public services is provided; increasing the accountability of local governments in order to prevent corruption; involvement of the population in active participation in development policy of rural areas. We agree with the scientific position of Ukrainian scientists that without the active position of local residents it is impossible to successfully implement the principles of fiscal decentralization in the country, as well as to ensure efficient use of taxpayers' funds without accountability at all levels of government (Oparin V., Sarnetska Y., 2020).

\section{References:}

1. Baskaran, T., Feld, T. P. (2012). Fiscal Decentralization and Economic Growth in OECD Countries: is there a Relationship. Public Finance Review, 41/4, pp. 421-445.

2. Boiko, S. V. (2016). Fiskalnyi Potentsial Mistsevykh Podatkiv i Zboriv: Klasternyi Analiz Rehioniv Ukrainy (Fiscal Potential of Local Taxes And Fees: Cluster Analysis of The Regions Of Ukraine). Naukovyi visnyk Polissia, 3, pp. 106-111.

3. Boiko, S. V., Drahan, O. O. (2016). Podatok Na Dokhody Fizychnykh Osib U Formuvanni Finansovykh Resursiv Rozshyrenoho Uriadu (Tax On Incomes Of Individuals In The Formation Of Financial Resources Of The Expanded Government). Ekonomichnyi chasopys- XXI, 161, pp. 35-38.

4. Boschmann, N. (2009). Fiscal Decentralization and Options for Donor Harmonization, Development Partners Working Group on Local Governance and Decentralization DPWG-LGD - Retrieved: http://www.nalas.eu/knowledge-center/Fiscal-Decentralization-Options-for-Donor-Harmonisation. Access: 01.01.2020.

5. Budget Code of Ukraine on July 8, 2010 № 2456-VI. Retrieved: https://zakon.rada.gov.ua/laws/show/245617 ?lang=en\#Text. Access: 01.01.2021.

6. Davoodi, H., Zou, H. (1998). Fiscal Decentralization and Economic Growth: A Cross-Country Study. Journal of Urban Economics, 43, pp. 244-257.

7. Davydenko, N. (2016). Vplyv Podatkovoi Reformy Na Silskohospodarski Pidpryiemstva (Impact Of The Tax Reform On Agricultural Enterprises). Visnyk Khmelnytskoho natsionalnoho universytetu. Ekonomichni nauky, 31, pp. 250-253.

8. Davydenko, N., Pasichnyk, Y. (2017). Features of Socio-Economic Development of The Baltic States and Ukraine. Baltic Journal of Economic Studies, 3(5), pp. 97-102.

9. Decentralization (2021). Retrieved: https://decentralization.gov.ua/. Access: 01.01.2021.

10. European Charter of Local Self-Government of November 16, 2009. Retrieved: http://zakon.rada.gov.ua/laws/show/994_036. Access: 01.01.2021.

11. Government revenue, expenditure and main aggregates. Retrieved: https://ec.europa.eu/eurostat/databrowser/view/GOV_10A_MAIN_custom_394737/default/table?lang=en. Access: 01.01.2021.

12. On Voluntary Unification of Territorial Communities: Law of Ukraine on February 5, 2015 № 157-VIII. Retrieved: https://zakon.rada.gov.ua/laws/show/157-19?lang=en\#Text. Access: 01.01.2021.

13. On Approval Of The Concept Of Reforming Local Self-Government And Territorial Organization Of Power In Ukraine: Order of the Cabinet of Ministers of Ukraine on April 1, 2014 № 333-p. Retrieved: http://zakon5.rada.gov.ua/laws/show/333-2014-\%D1\%80. Access: 01.01.2021.

14. On approval of the Methodology for the formation of affluent territorial communities: Resolution of the Cabinet of Ministers of Ukraine on April 8, 2015 № 214. Retrieved: https://zakon.rada.gov.ua/laws/show/214-2015$\%$ D0\%BF?lang=en\#Text. Access: 01.01.2021.

15. Oparin, V. M., Sarnetska, Ya. A. (2020). Imperatyvy biudzhetnoho rehuliuvannia $v$ Ukraini $v$ umovakh fiskalnoi detsentralizatsii (Imperatives of budget regulation in Ukraine in the conditions of fiscal decentralization). Finansy Ukrainy, 1., pp. 58-72. 
Proceedings of the 2021 International Conference "ECONOMIC SCIENCE FOR RURAL DEVELOPMENT" Jelgava, LLU ESAF, 11-14 May 2021, pp. 102-114 DOI: $10.22616 / E S R D .2021 .55 .010$

16. Statistical publication "Budget of Ukraine". Retrieved: https://www.mof.gov.ua/uk/statistichnij-zbirnik. Access: 01.01.2021.

17. Tanzi, V. (1995). Fiscal Federalism and Decentralization: A Review of Some Efficiency and Macroeconomic Aspects. The World Bank Research Observer, pp. 295-316.

18. Thiessen, U. (2003). Fiscal Decentralization and Economic Growth in High Income OECD Countries. Fiscal Studies, 24, pp. 237- 274.

19. Thornton, J. (2007). Fiscal Decentralization and Economic Growth Reconsidered. Journal of Urban Economics, 61(1), pp. 64-70. 